\title{
Assessment of correlation between markers of ambient monitoring and biological monitoring of dimethylformamide for workers in synthetic leather manufacturing factories in Korea
}

\author{
Yang In Hwang' ${ }^{1,}$, Mi-Young Lee ${ }^{1}$, Yun Kyung Chung² and Eun A Kim ${ }^{1}$ \\ ${ }^{1}$ Occupational Safety and Health Research Institute, Korea Occupational Safety and Health Agency \\ ${ }^{2}$ Hallym University Sacred Heart Hospital, Anyang, 431-070, Korea \\ (Received September 2, 2013; Revised September 30, 2013; Accepted September 30, 2013)
}

\section{국내 합성피혁제조업 근로자에 대한 디메틸포름아미드의 공기중 농도와 생물학적 노출지표간의 상관성 평가 \\ 황양인 ${ }^{1} \star \cdot$ 이미영 ${ }^{1} \cdot$ 정윤경 ${ }^{2} \cdot$ 김은아 ${ }^{1}$ \\ 1한국산업안전보건공단 산업안전보건연구원, ${ }^{2}$ 한림대학교병원 \\ (2013. 9. 2. 접수, 2013. 9. 30. 수정, 2013. 9. 30. 승인)}

\begin{abstract}
The possibility of acute hepatotoxicity caused by dimethylformamide (DMF) requires regular monitoring of the workers who are using DMF to prevent the occupational disease. The authors performed ambient and biological monitoring of workers involved in synthetic leather manufacturing processes using DMF to assess the correlation between the markers of ambient and biological monitoring of DMF. The authors monitored 142 workers occupationally exposed to DMF from 19 workshops in the synthetic leather and ink manufacturing industries located in northern region of Gyeonggi-do. The subjects answered questionnaire on work procedure and use of personal protective equipment to be classified by exposure type. DMF in air samples collected using personal air samplers, diffusive and active sampler, was analysed using gas chromatograph-flame ionization detector (GC-FID) with DBFFAP column (length $30 \mathrm{~m}$, i.d. $0.25 \mathrm{~mm}$, film thickness $0.25 \mu \mathrm{m}$ ). Urinary $\mathrm{N}$-methylformamide (NMF) was analysed using gas chromatograph-mass selective detector (GC-MSD) at selected ion monitoring (SIM) mode with DB-624 column (length $60 \mathrm{~m}$, i.d. $0.25 \mathrm{~mm}$, film thickness $1.40 \mu \mathrm{m}$ ). Geometric mean (GM) and geometric standard deviation (GSD) of the ambient DMF was $6.85 \pm 3.43 \mathrm{ppm}$, and GM and GSD of urinary NMF was $42.3 \pm 2.7$ $\mathrm{mg} / \mathrm{L}$. The ratio of subjects with DMF level over $10 \mathrm{ppm}$ was $44 \%$, and those with urinary NMF over $15 \mathrm{mg} /$ $\mathrm{L}$ was $87 \%$. NMF in urine adjusted by DMF in air was $4.61 \pm 2.57 \mathrm{mg} / \mathrm{L} / \mathrm{ppm}$ and $9.50 \pm 2.41 \mathrm{mg} / \mathrm{L} / \mathrm{ppm}$, respectively, with or without respirator. There was seasonal differences of NMF in urine adjusted by DMF in air, $7.63 \pm 2.74 \mathrm{mg} / \mathrm{L} / \mathrm{ppm}$ in summer and $4.53 \pm 2.29 \mathrm{mg} / \mathrm{L} / \mathrm{ppm}$ in winter. The urinary NMF concentration which corresponds to $10 \mathrm{ppm}$ of ambient DMF was $52.7 \mathrm{mg} / \mathrm{L}(\mathrm{r}=0.650, \mathrm{n}=128)$. Considering the difference of the route of exposure which resulted from the compliance of wearing personal protective equipment, the estimated contribution of respiratory and dermal exposure route for DMF was $48.5 \%$ vs. $51.5 \%$.
\end{abstract}

Key words: Dimethylformamide (DMF), N-Methylformamide (NMF), biological monitoring, occupational exposure, dermal exposure, personal protective equipment

$\star$ Corresponding author

Phone : +82-(0)32-510-0827 Fax : +82-(0)32-518-0862

E-mail : hw877@kosha.net 


\section{1. 서 론}

합성피혁제조사업장에서 피혁코팅용 우레탄 수지의 용매로 사용되는 디메틸포름아미드(Dimethylformamide, $\mathrm{DMF}$ )는 인체에 대해 간독성이 있는 것으로 알려져 있으며, 우리나라에서는 1993년 DMF로 인한 독성 사 례가 처음 보고된 후 독성 간염 중독 사례와 복통 등의 증상을 호소하는 사례가 지속적으로 발생하고 있다.,2

$\mathrm{DMF}$ 취급 근로자의 화학 물질에 의한 건강 장해를 예방하기 위하여 국내외에서 직업적 노출 기준을 정 하였으며, 작업장 내 공기 중 노출기준(Threshold limit value, TLV)은 1 일 작업 시간 동안의 시간가중 평균 노출 기준(Time weighted average, TWA)으로 $\mathrm{DMF}$ 의 노출 기준은 $10 \mathrm{ppm}\left(30 \mathrm{mg} / \mathrm{m}^{3}\right)$ 이다., ${ }^{3,4} \mathrm{DMF}$ 는 피부를 통해 흡수되어 전신에 영향을 끼치는 물질 로 직업적 노출기준에 “피부”라고 주의 사항이 표시 되어 있다. 또한 혈액이나 소변 등의 생체시료를 분석 하여 근로자의 유해 물질 노출 정도를 파악하는 생물 학적 노출 평가(Biological monitoring)를 위해서 $\mathrm{DMF}$ 의 대사산물인 N-메틸포름아미드(N-Methylformamide, $\mathrm{NMF}$ )를 생물학적 노출 지표로 규정하고 있으며, 작업 종료 직후 채취한 소변 중 $\mathrm{NMF}$ 의 국내 노출 기준은 $15 \mathrm{mg} / \mathrm{L}$ 으로 규정되어 있다. ${ }^{5,6}$

$\mathrm{DMF}$ 노출의 생물학적 노출지표인 소변 중 $\mathrm{NMF}$ 는 $\mathrm{DMF}$ 에 노출된 근로자의 1 일 노출 지표이며, 공기 중 $\mathrm{DMF}$ 의 농도, 노출 경로, 피부 흡수 조건에 따라 영향을 받는다. ${ }^{7}$ Lauwerys 등은 공기 중 $\mathrm{DMF}$ 농도 와 소변 중 $\mathrm{NMF}$ 의 배설량과는 유의한 상관관계를 보 이며, 특히 아무런 개인 보호구가 없을 때에는 호흡보 다는 피부 흡수가 더 중요하여 불투과성의 보호 장갑 착용이 $\mathrm{DMF}$ 의 피부 흡수를 방지하는 방법이라고 제 시하고 있다. DMF에 의한 피부 흡수는 취급 물질의 물리적 성상, 작업 환경에 영향을 받는다. $\mathrm{DMF}$ 용액 에 한쪽 손을 10 분간 담그는 것은 8 시간 동안 10 $\mathrm{ppm}$ 의 $\mathrm{DMF}$ 에 노출된 것과 같으며, 온도와 습도가 증가함에 따라 피부 노출량은 증가하고, ${ }^{9} \mathrm{DMF}$ 증기 의 피부를 통한 흡수는 약 $40 \%$ 로 피부 흡수의 중요 성이 강조되고 있다. ${ }^{10}$

$\mathrm{DMF}$ 에 대한 국내 연구는 주로 건강 장해 및 사 례, ${ }^{11,12}$ 생물학적 대사물질 측정에 관한 연구, ${ }^{13,14}$ 건강 장해 사례, ${ }^{14}$ 생물학적 노출 평가에 영향을 미치는 인 자에 관한 연구, ${ }^{15,16}$ 작업환경 및 보건관리 실태 ${ }^{17}$ 와 표준 환기 방안 18 등이 연구되었다. 또한 $\mathrm{DMF}$ 취급 근로자 노출실태에 대해 1998년 한국산업안전보건공
단 산업안전보건연구원에서 $\mathrm{DMF}$ 를 취급하는 사업장 을 대상으로 정밀 역학조사를 실시한 바 있으며 ${ }^{19}$ (한 국산업안전보건공단, 1999), 합성피혁사업장에 대한 공기 중 노출실태 및 소변 중 $\mathrm{NMF}$ 에 대한 연구가 있 었다. ${ }^{20}$ 그러나 이러한 연구에서 국내 근로자에 대해 공기 중 $\mathrm{DMF}$ 농도와 소변 중 대사물질간의 상관관계 를 다룬 구체적인 사항이 부족하였으며 특히, 근로자 노출에 영향을 미치는 보호구 착용 여부, 계절 영향에 대한 조사가 미흡하였다. 본 연구에서는 $\mathrm{DMF}$ 의 공기 중 농도와 소변 중 대사물질 농도 간 상관관계를 평 가하고 보호구 착용에 의한 영향을 조사하여, 공기 노 출 및 피부 노출이 생물학적 노출 평가에 미치는 영 향을 제시하고자 하였다.

\section{2. 연구방법}

\section{1. 연구 대상}

$\mathrm{DMF}$ 를 취급하고 있는 경기 북부 지역의 19 개(피 혁 코팅 업체 16 개소 및 코팅용 잉크 제조업체 3 개 소) 사업장에서 배합, 코팅, 합지 · 권취, 박리 · 포장, 잉 크 생산 공정의 근로자 142 명에 대하여 보호구 착용 실태 등 현장 조사를 실시하고 근로자의 공기 중 $\mathrm{DMF}$ 와 생물학적 노출지표인 소변 중 $\mathrm{NMF}$ 를 측정 하였다. 본 연구는 가톨릭대학교 기관 윤리 심의위 원회(Institutional Review Boards, IRB)의 승인(연구번 호 CUMC10U130)을 받고 진행하였다.

\section{2. 시료 채취}

\subsection{1. 공기 중 $\mathrm{DMF}$}

공기 중 $\mathrm{DMF}$ 노출 평가를 위하여 근로자 개인에게 능동형 및 수동형 개인시료 포집기를 장착하여 공기 중 DMF 시료를 채취하였다. 능동형 시료 포집을 위 하여 개인 시료 채취기(personal low volume air sampler, Gillian, U.S.A.)에 실리카겔 흡착튜브(SKC Tube, silica gel $150 \mathrm{mg} / 75 \mathrm{mg}$, Cat. No, 226-10, U.S.A.)를 연결 하여 유량 0.01 1.0 L/min으로 6 시간 이상 채취하였 고, 채취한 시료는 양쪽 끝을 막은 후 냉장 상태로 운 반하였다. 한편 작업자가 펌프 착용을 기피한 경우에 는 수동 포집기(passive sampler, 3M, U.S.A.)를 사용 하였다.

\subsection{2. 소변 중 NMF}

연구 대상 근로자의 소변은 공기 중 $\mathrm{DMF}$ 시료 채 취를 실시한 날의 작업 종료 시에 채취하였다. 채취한 
소변은 냉장 상태로 실험실로 운반하였다.

\section{3. 분석 방법}

\subsection{1. 기구 및 시약}

디메틸포름아미드, $\mathrm{N}$-메틸포름아미드 표준시약은 Aldrich사(U.S.A.)의 특급시약을 사용하였고, 시료 전 처리용 메탄올은 Merck사(U.S.A.)의 크로마토그라피급 용매를 사용하였다. 탈이온수는 Millipore사(U.S.A.)의 Milli-RO와 Milli-Q water system으로 실험실에서 제 조하여 사용하였다. 시료 희석 및 여과를 위해 cluster tube (Corning사, U.S.A.), 96-well 여과장치(Varian, U.S.A.)를 사용하였으며, 여과용 filter plate는 $0.45 \mu \mathrm{m}$ 규격이었다. 시약 이동 및 시료 혼합에는 8-channel pipette (Vistalab, U.S.A.)을 사용하였다. 소변 중 NMF 분석 시 소량의 검액을 $\mathrm{GC}$ 에 주입하기 위해 conical insert (Agilent, U.S.A.)를 $2 \mathrm{~mL} \mathrm{GC}$ 용 바이알에 삽입 하였다. 공기 중 $\mathrm{DMF}$ 분석에 사용한 장비는 Agilent 사(U.S.A.)의 6890 Series GC-FID (flame ionization detector)이며, 소변 중 NMF 분석에는 6890 Series $\mathrm{GC} / \mathrm{HP}-5973$ 가스크로마토그래프-질 량분석검출기를 사용하였다. 자동 시료 주입기는 7683 series (Agilent, U.S.A)를 사용하였다. 분석용 컬럼으로 공기 중 $\mathrm{DMF}$ 분석에는 DB-FFAP column (길이 $30 \mathrm{~m}$, 내경 0.25 $\mathrm{mm}$, 막두께 $0.25 \mu \mathrm{m}, \mathrm{J} \& \mathrm{~W}$ Scientific Inc., U.S.A.), 소변 중 NMF 분석에는 DB-624 (길이 $60 \mathrm{~m}$, 내경 0.25 $\mathrm{mm}$, 막두께 $1.40 \mu \mathrm{m}, \mathrm{J} \& \mathrm{~W}$ Scientific Inc., U.S.A.)를 사용하였다. 이동상은 $99.9999 \%$ 의 초고순도 헬륨 (SeongGang, Korea)을 사용하였다.

\subsection{2. 표준용액 제조}

$\mathrm{DMF} 17 \mathrm{mg}$ 을 정밀하게 재어 $10 \mathrm{~mL}$ 용량플라스크 에 넣고 메탄올로 표선을 채워 $1,700 \mathrm{mg} / \mathrm{L}$ 표준용액 을 만들고 이것을 표준용액 원액으로 하였다. 표준용 액 원액 $1 \mathrm{~mL}$ 를 취해 $10 \mathrm{~mL}$ 용량플라스크에 넣고 메탄올로 표선을 채워 $\mathrm{DMF} 170 \mathrm{mg} / \mathrm{L}$ 표준용액을 만 들었다. 이것을 다시 메탄올로 희석하여 DMF 1.7, $17,85,170 \mathrm{mg} / \mathrm{L}$ 용액을 만들었다. 공시료는 메탄올 로 하였다.

$\mathrm{NMF} 52.3 \mathrm{mg}$ 을 정밀하게 재어 $10 \mathrm{~mL}$ 용량플라스 크에 넣고 $\mathrm{NMF}$ 는 탈이온수로 표선을 채워 $5,230 \mathrm{mg} /$ $\mathrm{L}$ 표준용액을 만들고 이것을 표준용액 원액으로 하였 다. 표준용액을 탈이온수로 단계적으로 희석하여 $\mathrm{NMF} 2.6,7.9,13.1,26.2,52.3 \mathrm{mg} / \mathrm{L}$ 용액을 만들었다. 공시료는 탈이온수로 하였다.

\subsection{3. 시료 전처리}

공기 중 DMF 시료는 NIOSH analytical method 2004의 분석 방법에 따라 분석을 수행하였다. 개인시 료포집기로 채취한 흡착 튜브를 해체하여 $2 \mathrm{~mL} \mathrm{GC}$ 용 바이알에 옮기고 $1 \mathrm{~mL}$ 의 메탄올을 가한 후 60 분 간 시료 진탕기에서 탈착하였다. 수동 포집기로 채취 한 시료는 수동 포집기에 $2 \mathrm{~mL}$ 의 메탄올을 가한 후 60 분간 진탕하여 탈착한 메탄올 용액을 $2 \mathrm{~mL} \mathrm{GC}$ 용 바이알에 옮겨 검액을 제조하였다.

$\mathrm{NMF}$ 분석용 소변은 한국산업안전보건공단 안전보건 기술지침의 분석 방법에 따라 전처리를 수행하였다. ${ }^{20}$ 채취한 소변을 3 분간 잘 섞어준 후 $50 \mu \mathrm{L}$ 를 취하여 cluster tube에 옮긴 후 8-channel pipette을 사용하여 메탄올 $450 \mu \mathrm{L}$ 를 가한 후 8-channel pipette 혼합 모드 를 이용하여 시료를 혼합하였다. 혼합한 시료를 그대 로 96-well 필터 카트리지로 이동하여 진공에서 여과 한 여액을 검액으로 하였다.

\subsection{4. 회수율 시험}

공기 중 $\mathrm{DMF}$ 의 회수율을 구하기 위해 $2.83 \mathrm{mg} / \mathrm{L}$ 의 DMF 메탄올 용액을 제조한 후 이 용액을 메탄올 로 $1 / 3$ 로 희석하여 $0.94 \mathrm{mg} / \mathrm{L} \mathrm{DMF}$ 표준용액을 제조 하였다. 실리카겔 흡착 튜브에 $0.94 \mathrm{mg} / \mathrm{L} \mathrm{DMF}$ 메탄 올 용액을 $1,3,7 \mu \mathrm{L}, 2.83 \mathrm{mg} / \mathrm{L}$ 의 $\mathrm{DMF}$ 메탄올 용 액을 $10 \mu \mathrm{L} \mathrm{GC}$ 자동 시료 주입기용 주사기로 각각 1 $\mu \mathrm{L}$ 주입하고, 각 농도 당 2 개의 실리카겔 흡착 튜브 시료를 제조한 후 이를 메탄올 $1 \mathrm{~mL}$ 로 탈착한 시료 를 분석하여 $\mathrm{DMF}$ 의 회수율 및 정밀도를 구하였다. $\mathrm{DMF}$ 분석 결과를 회수율로 보정하여 공기 중 $\mathrm{DMF}$ 농도를 산출하였다.

\subsection{5. 분석 조건}

공기 중 $\mathrm{DMF}$ 분석을 위한 주입부 및 검출기 온도 는 $250{ }^{\circ} \mathrm{C}$ 로 설정하였고, 컬럼 온도는 $80{ }^{\circ} \mathrm{C}$ 에서 2 분 유지하고 $120{ }^{\circ} \mathrm{C}$ 까지 분당 $10{ }^{\circ} \mathrm{C}$ 의 속도로 온도를 올린 후 $120{ }^{\circ} \mathrm{C}$ 에서 3 분 유지하였다. 1 회당 분석 시 간은 9 분이었다. 시료를 $1 \mu \mathrm{L}$ 주입하였고 분할비는 $30: 1$, 유속은 $1.0 \mathrm{~mL} / \mathrm{min}$ 이었으며, $\mathrm{FID}$ 로 $\mathrm{DMF}$ 를 7.3 분에 검출하였다.

소변 중 $\mathrm{NMF}$ 분석 조건은 분할비 20:1에서 컬럼 유속은 $0.9 \mathrm{~mL} / \mathrm{min}$ 였으며, 검액 주입 량은 $1 \mu \mathrm{L}$ 였다. 주입부와 검출기 온도는 $250{ }^{\circ} \mathrm{C}$ 로 설정하였고, 컬럼 온도는 $100{ }^{\circ} \mathrm{C}$ 에서 2 분 유지하고 분당 $20{ }^{\circ} \mathrm{C}$ 의 온도 로 $200{ }^{\circ} \mathrm{C}$ 까지 상승시킨 후 $200{ }^{\circ} \mathrm{C}$ 에서 3 분 유지하 
였다. 다시 분당 $20{ }^{\circ} \mathrm{C}$ 의 온도로 $220{ }^{\circ} \mathrm{C}$ 까지 상승시 킨 후 $220{ }^{\circ} \mathrm{C}$ 에서 6 분 유지하였다. $\mathrm{NMF}$ 는 8.6 분에 검출되었으며, 1 회 분석에 소요된 시간은 17 분이었다. 질량분석검출기는 SIM 모드에서 $\mathrm{m} / \mathrm{z} 59$ 단일 이온만 을 선택하여 $\mathrm{NMF}$ 를 검출하였다. 제 40 회 국제 독일 정도관리 시료를 기지 시료로 활용하여 소변 시료와 같은 방법으로 분석하고, 그 기준값에 대한 분석값의 백분율을 구하여 분석의 정확도를 산출하였다.

\subsection{DMF 노출에 영향을 주는 요인}

설문지를 통해 근로자들의 음주 및 흡연 정도를 파악 하였으며, 보호구 착용 실태를 조사하기 위해 방독마스 크와 불침투성 유기화합물용 안전장갑을 작업현장에서 실제 착용하였는지 여부를 현장에서 직접 확인하였다.

\section{5. 자료 해석}

공기 중 $\mathrm{DMF}$ 농도가 소변 중 $\mathrm{NMF}$ 에 영향을 미치
므로 이 두 요인의 관련성을 조사하기 위해 두 값의 비 (소변 중 $\mathrm{NMF} /$ 공기 중 $\mathrm{DMF}$ )를 구하였다. 자료의 분포 특성을 파악하기 위하여 자료 수에 따라 KolmogorovSmirnov법(자료수 50 이상), Shapiro-Wilks 법(자료수 50 미만)을 적용하여 정규성을 검정하였다. Unpaired t-test를 이용하여 보호구 착용 유무, 계절 등의 요인에 대한 각 집단의 평균을 비교 분석하였고, 직무와 같이 요인별 집단이 2 개를 초과하는 경우에는 분산 분석 (ANOVA)을 실시하였다. 또한 공기 중 DMF 농도와 소변 중 $\mathrm{NMF}$ 농도간의 상관 관계 분석 및 회귀 분석 을 실시하였으며 통계 처리는 SPSS (version 18) 통계 프로그램을 이용하였다.

\section{3. 연구결과}

\section{1. 공기 중 $\mathrm{DMF}$ 노출 평가}

본 연구에 적용한 공기 중 $\mathrm{DMF}$ 분석 방법은 시료

Table 1. Concentration and excess ratio of DMF in air

\begin{tabular}{|c|c|c|c|c|c|c|c|}
\hline & \multirow{3}{*}{$\mathrm{n}^{\mathrm{a}}$} & \multicolumn{5}{|c|}{ "DMF in air (ppm) } & \multirow{3}{*}{ p value ${ }^{*}$} \\
\hline & & \multicolumn{2}{|c|}{ Excess ratio(n, \%) } & \multirow{2}{*}{$\mathrm{GM}^{\mathrm{b}}$} & \multirow{2}{*}{$\mathrm{GSD}^{\mathrm{c}}$} & \multirow{2}{*}{ Range } & \\
\hline & & $>10 \mathrm{ppm}$ & $>5 \mathrm{ppm}$ & & & & \\
\hline Total & 142 & $62(44 \%)$ & $87(61 \%)$ & 6.85 & 3.43 & $0.14-172.1$ & \\
\hline Industry $^{\dagger}$ & & & & & & & 0.001 \\
\hline - Synthetic leather & 124 & $54(44 \%)$ & $73(59 \%)$ & 6.19 & 3.56 & $0.14-172.1$ & \\
\hline - Ink manufacture & 18 & $11(61 \%)$ & $17(94 \%)$ & 13.75 & 2.09 & $3.96-50.70$ & \\
\hline Process ${ }^{*}$ & & & & & & & 0.099 \\
\hline - Mixing & 35 & $17(49 \%)$ & $21(60 \%)$ & 6.05 & 3.17 & $0.14-48.73$ & \\
\hline - Coating & 52 & $22(42 \%)$ & $29(56 \%)$ & 6.74 & 3.53 & $0.45-172.1$ & \\
\hline - Lamination & 20 & $7(35 \%)$ & $13(65 \%)$ & 6.53 & 3.17 & $0.39-40.39$ & \\
\hline - Desquamation \& Packing & 17 & $5(29 \%)$ & $7(41 \%)$ & 4.70 & 4.32 & $0.7-42.7$ & \\
\hline - Ink process & 18 & $11(61 \%)$ & $17(94 \%)$ & 13.75 & 2.09 & $3.96-50.70$ & \\
\hline$\overline{\operatorname{Mask}^{\dagger}}$ & & & & & & & 0.859 \\
\hline - Wear & 73 & $32(44 \%)$ & $44(60 \%)$ & 6.97 & 3.21 & $0.14-172.1$ & \\
\hline - Did not wear & 69 & $30(44 \%)$ & $43(62 \%)$ & 6.72 & 3.68 & $0.39-76.48$ & \\
\hline$\overline{\text { Season }^{\dagger}}$ & & & & & & & $<0.001$ \\
\hline - Summer(May-Oct) & 96 & $31(32 \%)$ & $49(51 \%)$ & 4.78 & 3.04 & $0.14-37.15$ & \\
\hline - Winter(Nov-Mar) & 46 & $31(67 \%)$ & $38(83 \%)$ & 14.48 & 3.12 & $0.83-172.1$ & \\
\hline$\overline{\text { Method }^{\dagger}}$ & & & & & & & 0.059 \\
\hline - Active sampler & 85 & $31(36 \%)$ & $50(59 \%)$ & 5.77 & 2.81 & $0.14-37.15$ & \\
\hline - Passive sampler & 57 & $31(67 \%)$ & $37(65 \%)$ & 14.48 & 3.12 & $0.39-172.1$ & \\
\hline
\end{tabular}

${ }^{\mathrm{a}} \mathrm{n}$ :number of subject, ${ }^{\mathrm{b}} \mathrm{GM}$ :Geometric mean, ${ }^{\mathrm{c}} \mathrm{GSD}$ : Geometric standard deviation

* p-value: p-value was calculated by unpaired t-test or ANOVA after log transformation of DMF concentration in air because the data of DMF showed log normal distribution..

${ }^{\dagger}$ Industry, Mask, Season, Method assessed by unpaired t-test

*Process was assessed by ANOVA test 
당 $0.04 \mathrm{mg}$ 의 검출 한계와 $82-90 \%$ 의 회수율을 나타 내었다. $\mathrm{DMF}$ 의 평균 회수율은 $86 \%$ 였으며, 종합 정밀 도(overall precision)는 0.052 였다.

경기북부지역 $\mathrm{DMF}$ 취급 19 개 업체 142 명 근로자 들의 공기 중 $\mathrm{DMF}$ 농도는 Kolmogorov-Smirnov 및 Shapiro-Wilks 정규성 검증을 실시한 결과 대수정규분 포를 하였으며 업종별, 직무별, 마스크 착용 유무, 계 절별 기하평균 농도 및 노출기준 초과율은 Table 1과 같다.

전체 근로자 $(\mathrm{n}=142$ 명 $)$ 의 공기 중 $\mathrm{DMF}$ 의 기하평균 농도는 $6.85 \mathrm{ppm}$ 으로 62 명 $(44 \%)$ 이 노출기준 $(10 \mathrm{ppm})$ 을 초과하였으며 87 명(61\%)이 노출기준의 0.5 배(5 $\mathrm{ppm})$ 를 초과하였다. 업종별로는 잉크 생산 업체 $(\mathrm{n}=18$ 명)의 기하평균농도는 $13.75 \mathrm{ppm}$ 으로 11 명 $(61 \%)$ 이 노 출기준 $(10 \mathrm{ppm})$ 을 초과하였으며, 피혁 코팅 업체 $(\mathrm{n}=124$ 명 $)$ 의 기하평균 농도는 $6.19 \mathrm{ppm}$ 으로 54 명 $(44 \%)$ 이 노출기준을 초과하여 잉크 생산 업체가 피혁
코팅 업체보다 평균 농도가 2 배 높았으며 업종간에 도 유의한 차이를 보였다 $(\mathrm{p}=0.001)$. 직무별로는 기하 평균농도가 $4.70 \mathrm{ppm}$ 부터 $13.75 \mathrm{ppm}$ 범위로, 잉크 생 산 업무가 가장 $\mathrm{DMF}$ 의 농도가 높았으며 $(13.75 \mathrm{ppm}$, $\mathrm{n}=18$ 명 $)$, 이후 코팅(6.53 ppm, $\mathrm{n}=52$ 명), 합지(6.53 $\mathrm{ppm}, \mathrm{n}=20$ 명 $)$, 배합(6.05 ppm, $\mathrm{n}=35$ 명) 순으로 낮게 나타났고, 가장 $\mathrm{DMF}$ 의 농도가 낮은 직무는 박리 - 포 장 등 후처리 직무 $(4.70 \mathrm{ppm}, \mathrm{n}=17$ 명 $)$ 였으나, 직무간 에 유의한 차이는 없었다 $(\mathrm{p}=0.099)$.

호흡 보호구면에서는 보호구를 착용한 그룹 $(n=73$ 명 $)$ 의 기하평균 농도가 $6.97 \mathrm{ppm}$ 이고, 미착용 그룹 $(\mathrm{n}=69$ 명)이 $6.72 \mathrm{ppm}$ 으로 유의한 차이를 보이지 않았으나 $(\mathrm{p}=0.859)$, 측정 시기면에서는 동절기 $(11$ 월 4 월 $)$ 에 측 정한 경우 $(n=46$ 명 $)$ 의 기하평균 농도가 $14.48 \mathrm{ppm}$ 으로 하절기(5월 10 월 $)$ 에 측정한 경우 $(\mathrm{n}=96$ 명 $)$ 인 $4.78 \mathrm{ppm}$ 에 비해 3 배가량 높았으며 측정시기별로 유의한 차 이를 보였다 $(\mathrm{p}<0.001)$.

Table 2. Concentration and excess ratio of urinary NMF

\begin{tabular}{|c|c|c|c|c|c|c|c|c|c|}
\hline & \multicolumn{6}{|c|}{ Urinary NMF (mg/L) } & \multirow{2}{*}{\multicolumn{3}{|c|}{$\begin{array}{l}\text { Adjusted NMF } \\
(\mathrm{mg} / \mathrm{L} / \mathrm{ppm})^{\mathrm{d}}\end{array}$}} \\
\hline & \multirow{2}{*}{$\mathrm{n}^{\mathrm{a}}$} & \multicolumn{2}{|c|}{ Excess ratio $(\mathrm{n}, \%)$} & \multirow{2}{*}{$\mathrm{GM}^{\mathrm{b}}\left(\mathrm{GSD}^{\mathrm{c}}\right)$} & \multirow{2}{*}{ Range } & \multirow{2}{*}{$\mathrm{p}$ value ${ }^{*}$} & & & \\
\hline & & $>40 \mathrm{mg} / \mathrm{L}$ & $>15 \mathrm{mg} / \mathrm{L}$ & & & & $\mathrm{n}^{\mathrm{a}}$ & GM (GSD) & $\mathrm{p}$ value \\
\hline Total & 135 & $72(53 \%)$ & $117(87 \%)$ & $42.3(2.7)$ & $2.0-623.3$ & & 128 & $6.43(2.66)$ & \\
\hline Industry $^{\dagger}$ & & & & & & 0.231 & & & 0.025 \\
\hline - Synthetic leather & 117 & $63(54 \%)$ & $103(88 \%)$ & $40.7(2.7)$ & $2.0-623.3$ & & 110 & $6.95(2.68)$ & \\
\hline - Ink manufacture & 18 & $9(50 \%)$ & $14(78 \%)$ & $54.8(2.4)$ & $12.0-219.0$ & & 18 & $3.98(2.28)$ & \\
\hline Process ${ }^{*}$ & & & & & & 0.598 & & & 0.208 \\
\hline - Mixing & 35 & $18(51 \%)$ & $32(91 \%)$ & $46.0(2.6)$ & $10.0-400.2$ & & 33 & $7.77(2.44)$ & \\
\hline - Coating & 48 & $23(48 \%)$ & $39(81 \%)$ & $38.0(2.7)$ & $5.0-623.3$ & & 47 & $6.33(2.93)$ & \\
\hline - Lamination & 21 & $12(57 \%)$ & $17(81 \%)$ & $44.4(2.9)$ & $4.0-356.0$ & & 17 & $7.14(2.60)$ & \\
\hline - Desquamation \& Packing & 13 & $7(54 \%)$ & $12(92 \%)$ & $33.6(3.1)$ & $2.0-167.0$ & & 13 & $7.12(2.71)$ & \\
\hline - Ink process & 18 & $12(67 \%)$ & $17(94 \%)$ & $54.8(2.4)$ & $12.0-219.0$ & & 18 & $3.98(2.28)$ & \\
\hline$\overline{\text { Mask }^{\dagger}}$ & & & & & & $<0.001$ & & & $<0.001$ \\
\hline - Wear & 70 & $26(37 \%)$ & $57(81 \%)$ & $30.7(2.4)$ & $4.0-263.3$ & & 69 & $4.61(2.57)$ & \\
\hline - Did not wear & 65 & $46(70 \%)$ & $60(92 \%)$ & $59.8(2.7)$ & $6.0-400.2$ & & 59 & $9.50(2.41)$ & \\
\hline$\overline{\text { Season }^{\dagger}}$ & & & & & & $<0.001$ & & & 0.004 \\
\hline - Summer & 93 & $43(46 \%)$ & $76(82 \%)$ & $33.9(2.5)$ & $2.0-356.0$ & & 86 & $7.63(2.74)$ & \\
\hline - Winter & 42 & $29(69 \%)$ & $41(98 \%)$ & $69.1(2.6)$ & $12.0-263.3$ & & 42 & $4.53(2.29)$ & \\
\hline Method $^{\dagger}$ & & & & & & $<0.001$ & & & 0.648 \\
\hline - Active sampler & 76 & $31(41 \%)$ & $64(84 \%)$ & $33.0(2.4)$ & $4.0-356.0$ & & 75 & $6.22(2.69)$ & \\
\hline - Passive sampler & 59 & $41(69 \%)$ & $53(90 \%)$ & $62.5(2.9)$ & $2.0-623.3$ & & 53 & $6.74(2.64)$ & \\
\hline
\end{tabular}

${ }^{\mathrm{a}} \mathrm{n}$ : number of subject, ${ }^{\mathrm{b}} \mathrm{GM}$ : Geometric mean, ${ }^{\mathrm{c}} \mathrm{GSD}$ : Geometric standard deviation

${ }^{\mathrm{d}}$ Adjusted NMF (mg/L/ppm) is urinary NMF (mg/L) divided by DMF in air(ppm).

" p-value was calculated by unpaired t test or ANOVA after log transformation of NMF concentration in urinary.

†Industry, Mask, Season, Method assessed by unpaired t test

tProcess was assessed by ANOVA test 
한편 측정 방법별 차이 조사에서 근로자에게 확산 방식의 수동 채취 방법을 사용한 경우 $(n=57$ 명 $)$ 의 기 하평균농도는 $8.83 \mathrm{ppm}$ 으로 개인 시료 펌프를 사용한 능동 채취 방법 $(\mathrm{n}=85$ 명 $)$ 의 $5.77 \mathrm{ppm}$ 보다 높았으나 유 의한 차이는 보이지 않았다 $(\mathrm{p}=0.059)$.

\section{2. 소변 중 $\mathrm{NMF}$ 노출 평가}

본 연구에 적용한 소변 중 $\mathrm{NMF}$ 분석 방법의 검출 한계는 $1.8 \mathrm{mg} / \mathrm{L}$ 였으며 $(\mathrm{S} / \mathrm{N}=3)$, 독일 국제 정도관리 시료를 기지 시료로 이용하여 소변 중 $\mathrm{NMF}$ 를 정량하 고 그 회수율로 구한 $\mathrm{NMF}$ 분석의 정확도는 7.7-42.0 $\mathrm{mg} / \mathrm{L}$ 의 농도 범위에서 $93-111 \%$ 로, 기지시료의 적합 범위 내에 해당하였다.

작업 종료 후 측정한 생물학적 노출지표인 근로자 의 소변 중 NMF 농도는 Kolmogorov-Smirnov 및 Shapiro-Wilks 정규성 검증을 실시한 결과 대수정규분 포를 하였으며, 업종, 직무, 마스크 착용 여부, 계절별 기하평균 농도 및 생물학적 노출지표 초과율과 공기 중 $\mathrm{DMF}$ 농도를 보정한 보정비(소변 중 $\mathrm{NMF}$ /공기 중 $\mathrm{DMF})$ 는 Table 2와 같다.

전체 근로자 $(\mathrm{n}=135$ 명 $)$ 의 소변 중 $\mathrm{NMF}$ 의 기하평균 농도는 $42.3 \mathrm{mg} / \mathrm{L}$ 로 이 중 117 명 $(87 \%)$ 이 현재 노출지 표인 $15 \mathrm{mg} / \mathrm{L}$ 를 초과하였으며, 72 명 $(53 \%)$ 이 2006년 까지 적용되었던 노출지표인 $40 \mathrm{mg} / \mathrm{L}$ 를 초과하였다. 업종별로는 잉크 생산 업체 $(\mathrm{n}=18$ 명 $)$ 의 기하평균 농도 는 $54.8 \mathrm{mg} / \mathrm{L}$ 로 피혁코팅업체 $(\mathrm{n}=117$ 명 $)$ 의 기하평균농 도 $40.7 \mathrm{mg} / \mathrm{L}$ 보다 높았으나 유의한 차이를 보이지 않 았으며 $(\mathrm{p}=0.231)$, 공기 중 $\mathrm{DMF}$ 농도를 보정한 보정비 의 기하평균은 각각 $3.98 \mathrm{mg} / \mathrm{L} / \mathrm{ppm}, 6.95 \mathrm{mg} / \mathrm{L} / \mathrm{ppm}$ 으로 피혁 코팅 업체가 높았으며 유의한 차이를 보였 다 $(\mathrm{p}=0.025)$.

직무별로는 소변 중 $\mathrm{NMF}$ 의 기하평균 농도는 33.6 $\mathrm{mg} / \mathrm{L}$ 부터 $54.8 \mathrm{mg} / \mathrm{L}$ 범위로 잉크 생산 업무에서 가장 농도가 높았으며 $(54.8 \mathrm{mg} / \mathrm{L}, \mathrm{n}=18$ 명 $)$, 다음으로는 배 합(45.5 mg/L, n=35명), 합지(44.4 mg/L, n=21명), 코 팅 $(38.0 \mathrm{mg} / \mathrm{L}, \mathrm{n}=48$ 명 $)$, 박리 · 포장 $(33.6 \mathrm{mg} / \mathrm{L}, \mathrm{n}=13$ 명 $)$ 순으로 나타났으나 유의한 차이는 보이지 않았고 $(\mathrm{p}=0.648)$, 공기 중 $\mathrm{DMF}$ 농도를 보정한 보정비의 기 하평균은 피혁 코팅 업체의 직무가 $6.33 \mathrm{mg} / \mathrm{L} / \mathrm{ppm}$ 부 터 $7.77 \mathrm{mg} / \mathrm{L} / \mathrm{ppm}$ 으로 잉크 생산 직무 $3.98 \mathrm{mg} / \mathrm{L} /$ $\mathrm{ppm}$ 보다 높았으나 직무 간에 유의한 차이는 없었다 $(\mathrm{p}=0.208)$.

호흡보호구를 착용하지 않은 그룹 $(n=65$ 명 $)$ 의 기하 평균농도가 $59.8 \mathrm{mg} / \mathrm{L}$ 으로, 보호구를 착용한 그룹 $(\mathrm{n}=70$ 명 $)$ 의 기하평균 농도 $30.7 \mathrm{mg} / \mathrm{L}$ 보다 약 2 배 가 량 높았으며 공기 중 $\mathrm{DMF}$ 농도를 보정한 보정비의 기하평균도 각각 $9.50 \mathrm{mg} / \mathrm{L} / \mathrm{ppm}$ 과 $4.61 \mathrm{mg} / \mathrm{L} / \mathrm{ppm}$ 으 로 유의한 차이를 보였다 $(\mathrm{p}<0.001)$. 한편 측정 시기별 로 보면 동절기( 11 월 4 월 $)$ 에 측정한 경우 $(n=42$ 명 $)$ 의 기하평균 농도가 $69.1 \mathrm{mg} / \mathrm{L}$ 로 하절기(5월 10월)에 측 정한 경우 $(\mathrm{n}=93$ 명 $)$ 의 기하평균 농도 $33.9 \mathrm{mg} / \mathrm{L}$ 보다 2 배 가량 높았으나 $(\mathrm{p}<0.001)$, 공기 중 $\mathrm{DMF}$ 농도를 보 정한 보정비의 기하평균은 각각 $4.53 \mathrm{mg} / \mathrm{L} / \mathrm{ppm}$ 과 $7.63 \mathrm{mg} / \mathrm{L} / \mathrm{ppm}$ 으로 하절기에 측정한 경우가 동절기보 다 높았으며, 두 값은 유의한 차이를 보였다 $(\mathrm{p}=0.004)$.

한편 측정 방법별로 확산 방식의 수동채취기를 사 용한 근로자 $(\mathrm{n}=59$ 명 $)$ 의 기하평균 농도가 $62.5 \mathrm{mg} / \mathrm{L}$ 으 로 능동방식의 개인시료펌프를 착용한 근로자 $(\mathrm{n}=76$ 명 $)$ 의 기하평균 농도 $33.0 \mathrm{mg} / \mathrm{L}$ 보다 약 2 배 높게 유의 하게 나타났으나 $(\mathrm{p}<0.001)$, 공기 중 $\mathrm{DMF}$ 농도를 보정 한 보정비의 기하평균은 각각 $6.74 \mathrm{mg} / \mathrm{L} / \mathrm{ppm}$ 과 6.22 $\mathrm{mg} / \mathrm{L} / \mathrm{ppm}$ 으로 유의한 차이를 보이지 않았다 $(\mathrm{p}=0.648)$.

\section{3. 공기 중 $\mathrm{DMF}$ 와 소변 중 $\mathrm{NMF}$ 의 상관 관계}

공기 중 $\mathrm{DMF}$ 농도와 소변 중 $\mathrm{NMF}$ 농도는 모두 대수정규분포를 하였으며 이에 공기 중 $\mathrm{DMF}$ 농도와 소변 중 $\mathrm{NMF}$ 농도는 로그 변환한 값으로 선형 회귀 관계를 가졌다. 전체 근로자 $(\mathrm{n}=128$ 명 $)$ 에 대한 공기 중 $\mathrm{DMF}$ 와 소변 중 $\mathrm{NMF}$ 농도 간의 상관관계는 $\mathrm{r}=0.650$ 으 로 상관성이 높았으며 $(\mathrm{p}<0.001)$, 회귀관계식은 $\mathrm{Ln}(\mathrm{NMF})$ $=0.506 \times \mathrm{Ln}(\mathrm{DMF})+2.800$ 으로 공기 중 $10 \mathrm{ppm}$ 의 $\mathrm{DMF}$ 에 노출된 근로자의 소변 중 $\mathrm{NMF}$ 농도는 $52.7 \mathrm{mg} / \mathrm{L}$ 으로 추정되었다(Table 3).

또한 소변 중 $\mathrm{NMF}$ 에 영향을 미치는 호흡 보호구 착용 유무로 분석한 결과 마스크 착용 그룹 $(n=69$ 명 $)$ 의 경우 상관성은 $\mathrm{r}=0.610$ 이었고 $(\mathrm{p}<0.001)$, 공기 중 $10 \mathrm{ppm}$ 의 $\mathrm{DMF}$ 에 노출된 근로자의 소변 중 $\mathrm{NMF}$ 농 도는 $36.6 \mathrm{mg} / \mathrm{L}$ 로 추정되었다. 반면 마스크를 착용하지 않은 그룹 $(\mathrm{n}=59$ 명 $)$ 은 상관성이 $\mathrm{r}=0.775$ 였고 $(\mathrm{p}<0.001)$ 공기 중 $10 \mathrm{ppm}$ 의 $\mathrm{DMF}$ 에 노출된 근로자의 소변 중 $\mathrm{NMF}$ 농도는 $79.9 \mathrm{mg} / \mathrm{L}$ 로 마스크 착용 그룹에 비해 2 배 이상 높게 추정되었다(Fig. 1, Table 3).

땀 배출 등 피부 흡수에 영향을 미치는 계절별 요 인에 따른 공기 중 $\mathrm{DMF}$ 농도와 소변 중 $\mathrm{NMF}$ 농도 간의 상관성은 하절기가 $\mathrm{r}=0.533(\mathrm{p}<0.001)$ 이고 동절 기가 $\mathrm{r}=0.713(\mathrm{p}<0.001)$ 으로 동절기가 더 높았으며, 공 기 중 $10 \mathrm{ppm}$ 의 $\mathrm{DMF}$ 에 노출된 근로자의 소변 중 $\mathrm{NMF}$ 농도는 각각 $48.6 \mathrm{mg} / \mathrm{L}, 54.1 \mathrm{mg} / \mathrm{L}$ 로 추정되었 
Table 3. The correlation between DMF concentration in air and NMF concentration in urine and NMF in urine corresponding to $10 \mathrm{ppm}$ DMF in air

\begin{tabular}{|c|c|c|c|c|c|c|}
\hline & \multirow{2}{*}{ Category } & \multicolumn{4}{|c|}{ Regression parameter } & \multirow{2}{*}{$\begin{array}{l}\text { Estimated NMF } \\
\quad(\mathrm{mg} / \mathrm{L}) \text { for } \\
\mathrm{DMF}(10 \mathrm{ppm})\end{array}$} \\
\hline & & $\mathrm{n}$ & Regression equation & $r^{c}$ & p-value & \\
\hline & Total & 128 & $\mathrm{Y}^{\mathrm{a}}=0.506 \times \mathrm{X}^{\mathrm{b}}+2.800$ & 0.650 & $<0.001$ & 52.7 \\
\hline \multirow{2}{*}{ Method } & - Active sampler & 75 & $\mathrm{Y}=0.387 \times \mathrm{X}+2.850$ & 0.481 & $<0.001$ & 42.1 \\
\hline & - Passive sampler & 53 & $Y=0.538 \times X+2.936$ & 0.752 & $<0.001$ & 65.0 \\
\hline \multirow{2}{*}{ Industry } & - Synthetic leather & 110 & $Y=0.513 \times X+2.807$ & 0.665 & $<0.001$ & 54.0 \\
\hline & - Ink manufacture & 18 & $Y=0.560 \times X+2.536$ & 0.479 & 0.044 & 45.9 \\
\hline \multirow{5}{*}{ Process } & - Mixing & 33 & $\mathrm{Y}=0.545 \times \mathrm{X}+2.859$ & 0.714 & $<0.001$ & 61.2 \\
\hline & - Coating & 47 & $\mathrm{Y}=0.427 \times \mathrm{X}+2.891$ & 0.580 & $<0.001$ & 48.1 \\
\hline & - Lamination & 17 & $Y=0.648 \times X+2.618$ & 0.693 & 0.002 & 61.0 \\
\hline & - Desquamation \& Packing & 13 & $Y=0.560 \times X+2.645$ & 0.788 & 0.001 & 51.1 \\
\hline & - Ink process & 18 & $Y=0.560 \times X+2.536$ & 0.479 & 0.044 & 45.9 \\
\hline \multirow{2}{*}{ Mask } & - Wear & 69 & $\mathrm{Y}=0.443 \times \mathrm{X}+2.579$ & 0.610 & $<0.001$ & 36.6 \\
\hline & - Did not wear & 59 & $Y=0.554 \times X+3.105$ & 0.775 & $<0.001$ & 79.9 \\
\hline \multirow{2}{*}{ Season } & - Summer (May-Oct) & 86 & $\mathrm{Y}=0.440 \times \mathrm{X}+2.870$ & 0.532 & $<0.001$ & 48.6 \\
\hline & - Winter (Nov-Mar) & 42 & $Y=0.578 \times X+2.660$ & 0.713 & $<0.001$ & 54.1 \\
\hline \multirow{2}{*}{ Method } & - Active sampler & 75 & $\mathrm{Y}=0.387 \times \mathrm{X}+2.850$ & 0.481 & $<0.001$ & 42.1 \\
\hline & - Passive sampler & 53 & $Y=0.538 \times X+2.936$ & 0.752 & $<0.001$ & 65.0 \\
\hline
\end{tabular}

${ }^{\mathrm{a}} \mathrm{Y}: \log$ transformation of NMF concentration in urinary $(\mathrm{Ln}(\mathrm{NMF}))$.

${ }^{b} \mathrm{X}: \log$ transformation of DMF concentration in air $(\operatorname{Ln}(\mathrm{DMF}))$.

${ }^{c} \mathrm{r}$ : Pearson correlation coefficient

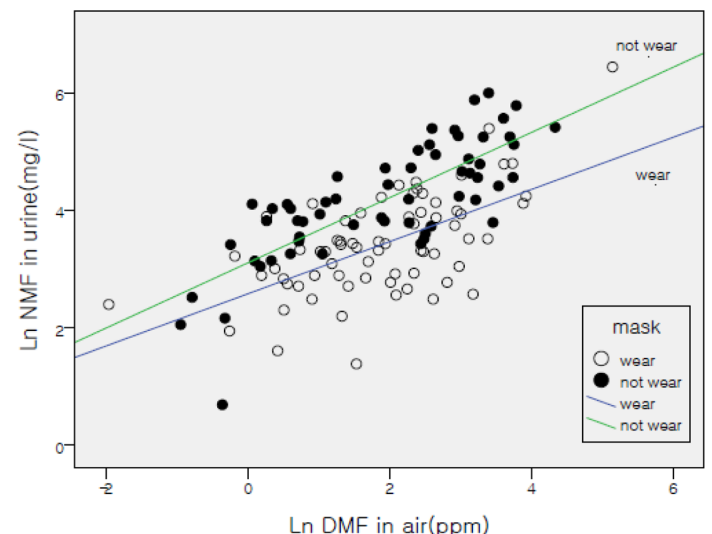

Fig. 1. Plot of urinary NMF and DMF in air for groups classified by wearing safety mask or not.

다(Fig. 2, Table 3).

\section{4. 고 찰}

본 연구 결과 $\mathrm{DMF}$ 를 취급하는 경기북부지역 합성 피혁 코팅 업체 및 코팅용 잉크 생산 업체의 전체 근

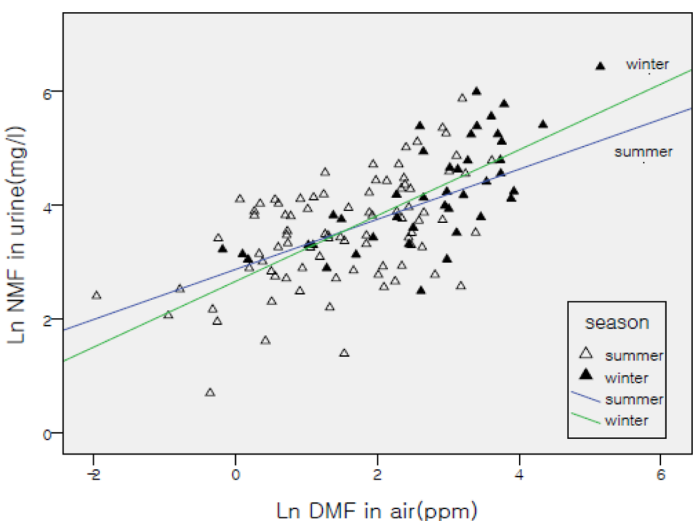

Fig. 2. Plot of urinary NMF and DMF in air for different seasons
로자 $(\mathrm{n}=142$ 명 $)$ 의 공기 중 $\mathrm{DMF}$ 의 노출 실태는 기하평 균 농도가 $6.85 \mathrm{ppm}$ 이며, 시간가중평균노출기준 10 $\mathrm{ppm}$ 초과율은 $44 \%$ 로 전체 근로자의 절반 가량이 노 출기준을 초과하는 것으로 나타났다. 이는 최호춘 등 이 수행한 경인지역 합성피혁 근로자 $(\mathrm{n}=98$ 명 $) \mathrm{DMF}$ 노출에 대한 연구결과인 $9.03 \mathrm{ppm}, 40.8 \%$ 와, 1998 년 
한국산업안전보건공단 산업안전보건연구원이 수행한 전국 단위의 $\mathrm{DMF}$ 취급사업장 역학조사 결과 합성피혁 제조업 사업장 $(\mathrm{n}=136$ 명 $)$ 의 평균 $\mathrm{DMF}$ 농도인 $0.8 \sim 20.9$ $\mathrm{ppm}, 41.1 \%$ 와 유사한 수준이었다. 이처럼 합성 피혁 관련 근로자들의 공기 중 $\mathrm{DMF}$ 노출이 높은 것은 작 업 특성이 인력에 의존하며, 사업장 규모가 50 인 미만 으로 영세하고, 허수종 등이 작업장내 환기 실태를 평 가한 결과 국소배기후드의 제어풍속 불합격률이 $65.5 \%$ 나 되는 등 ${ }^{17}$ 작업장 환기관리가 이루어지지 못 하였기 때문인 것으로 보인다. 공기 중 $\mathrm{DMF}$ 노출 수 준에 따른 건강 영향 평가에서 혈청 간효소 증가는 대략 1-6 ppm 정도에서는 혈청 간효소의 증가가 나타 나지 않았으나 $7 \mathrm{ppm}$ 이상의 높은 수준에서는 혈청 간효소가 증가한다는 점을 고려하였을 때 $\mathrm{DMF}$ 에 의 한 건강장애가 우려된다. ${ }^{22}$ 또한 동절기(11월 4월)가 $14.48 \mathrm{ppm}$ 으로 하절기(5월 10월) $4.78 \mathrm{ppm}$ 에 비해 3 배 가량 높았는데 그 이유는 하절기의 경우 창문 및 출입문 등을 개방하지만 동절기는 창문 등을 모두 닫 고 작업함에 따라 배기되지 못한 증기가 작업장내로 확산되기 때문이라 생각된다. 또한 합성 피혁 코팅 업 체 및 코팅용 잉크 생산 업체는 모두 주간 근무 (08:00 17:00)만 실시하고 있었으나, 작업 물량이 주문 제 방식에 의존하는 경우가 많아 2 시간 정도의 잔업 이 있는 경우가 잦았으며, 피혁 코팅 업체는 작업 설 비가 컨베이어 형태로 운영되어 평균 노출시간은 6 시간 이상으로, 코팅 기계 가동시간에 의존하였다.

$\mathrm{DMF}$ 노출에 따른 근로자의 내부 노출을 평가하는 소변 중 $\mathrm{NMF}$ 노출 평가에서 전체 근로자 $(\mathrm{n}=135$ 명 $)$ 의 기하평균농도는 $42.3 \mathrm{mg} / \mathrm{L}$ 였으며 생물학적 노출지표 를 초과한 근로자의 비율은 현재 기준인 $15 \mathrm{mg} / \mathrm{L}$ 를 적용하였을 경우에는 $87 \%, 2006$ 년 이전 기준인 40 $\mathrm{mg} / \mathrm{L}$ 를 적용한 경우에는 $53 \%$ 였다. 이는 최호춘 등 20 이 수행한 경인지역 합성 피혁 근로자 $(\mathrm{n}=98$ 명 $)$ 의 소 변 중 $\mathrm{NMF}$ 기하평균 농도 $56.2 \mathrm{mg} / \mathrm{L}, 63 \%(40 \mathrm{mg} / \mathrm{L}$ 초과 근로자 비율)보다 다소 낮았으나, 최호춘 등의 연구 대상이 $\mathrm{DMF}$ 의 고노출 집단(습식 코팅 및 습식 배합 등)에 대한 연구이므로 결국 유사한 경향을 나타 낸 것으로 볼 수 있으며, 1998년 한국산업안전보건공 단 산업안전보건연구원이 수행한 전국 단위의 $\mathrm{DMF}$ 취급사업장 역학조사 결과에서 나타난 합성피혁제조 업 사업장 $(\mathrm{n}=213$ 명) 평균 $9.8 \sim 127.7 \mathrm{mg} / \mathrm{L}, 29 \%$ (40 $\mathrm{mg} / \mathrm{L}$ 초과 근로자 비율)보다 높았다. 따라서 이번 연 구 결과에서 구한 생물학적 노출지표(소변 중 $\mathrm{NMF)}$ 는 현재 기준인 $15 \mathrm{mg} / \mathrm{L}$ 를 초과한 근로자의 비율이
$87 \%$ 이며, 1998 년 전국 $\mathrm{DMF}$ 취급사업장 역학조사 결 과 DMF가 $7 \mathrm{ppm}$ 이상인 고폭로군에서 간기능 이상 발생률이 높아진다는 사실을 고려할 때 생물학적 노 출지표인 소변 중 $\mathrm{NMF}$ 기준 $(15 \mathrm{mg} / \mathrm{L})$ 에 대한 재검 토가 필요함을 시사한다.

이번 연구결과 $\mathrm{DMF}$ 취급 근로자의 대다수가 피부 노출을 방지하기 위한 보호 장갑 및 보호복을 착용하 지 않고 있었으며, 호흡기 노출을 방지하기 위한 방독 마스크 착용도 전체 142 명 중 73 명만 착용하고 작업 하고 있어 착용률이 $51 \%$ 정도에 불과했다. 보호구 착 용유무에 따른 소변 중 $\mathrm{NMF}$ 노출실태를 살펴보면 방 독마스크를 착용한 그룹 $(\mathrm{n}=70$ 명 $)$ 의 기하평균농도는 $30.7 \mathrm{mg} / \mathrm{L}$ 이고, 착용하지 않은 그룹 $(\mathrm{n}=65$ 명 $)$ 은 59.8 $\mathrm{mg} / \mathrm{L}$ 로 나타났으며, 공기 중 $\mathrm{DMF}$ 농도를 보정한 경 우 기하평균농도가 각각 $4.61 \mathrm{mg} / \mathrm{L} / \mathrm{ppm}, 9.50 \mathrm{mg} / \mathrm{L} /$ $\mathrm{ppm}$ 로 나타나 방독마스크를 착용하지 않은 그룹이 착 용한 그룹보다 2 배 높게 나타났으며 통계적으로 유 의하였다 $(\mathrm{p}<0.001)$. 방독마스크를 착용한 그룹은 주로 피부로 노출되고 방독마스크를 착용하지 않은 그룹은 피부노출 및 호흡기노출에 기인한다고 볼 때, 피부노출 과 호흡기노출 비는 $48.5 \%: 51.5 \%$ 로 나타나 Nomiyama 등 $^{10}$ 의 $\mathrm{DMF}$ 증기의 피부를 통한 흡수 $40 \%$ 보다 다소 높으며 이는 실제 작업 중 증기를 통한 피부 흡수 이 외에 액체 취급에 의한 피부 흡수가 영향을 미친 것 으로 생각된다. 특히 본 연구에서 조사된 배합, 코팅, 박리, 권취포장, 잉크 제조 작업은 자동화되지 않은 인력작업으로 배합, 코팅 및 잉크 작업자는 $\mathrm{DMF}$ 가 함유된 액체를 바가지 등 용기를 이용하여 작업을 수 행함에 따라 작업자의 장갑, 작업복, 신발 등이 $\mathrm{DMF}$ 등 유기용제로 오염되어 있었으며, 박리 및 권취·포 장 작업의 경우 $\mathrm{DMF}$ 가 완전히 증발되지 않은 원단을 직접 손으로 취급하는 작업을 반복 수행함에 따라 $\mathrm{DMF}$ 증기 이외에도 과다한 피부노출이 있었던 것으 로 추정된다.

한편 피부 흡수와 관련한 온도 및 습도에 대한 영 향을 알아보기 위해 계절별 근로자의 소변 중 $\mathrm{NMF}$ 농도를 조사한 결과, 동절기 $(\mathrm{n}=42$ 명 $)$ 의 소변 중 $\mathrm{NMF}$ 기하평균농도는 $69.1 \mathrm{mg} / \mathrm{L}$ 로 하절기( $\mathrm{n}=93$ 명) 33.9 $\mathrm{mg} / \mathrm{L}$ 에 비해 2 배 높게 나타나 $(\mathrm{p}<0.001)$ 이광영 등 15 이 하절기가 동절기보다 2.6 배 높았다는 점과 상이한 것으로 나타났으나, 본 연구 결과 계절별 공기 중 $\mathrm{DMF}$ 농도는 동절기( $\mathrm{n}=46$ 명) $14.48 \mathrm{ppm}$ 이고 하절기 $(\mathrm{n}=96$ 명) $4.78 \mathrm{ppm}$ 으로 동절기가 하절기보다 3 배 높 았기 때문이며, 공기 중 $\mathrm{DMF}$ 농도를 보정한 경우 기 
하평균농도가 각각 $4.53 \mathrm{mg} / \mathrm{L} / \mathrm{ppm}, 7.63 \mathrm{mg} / \mathrm{L} / \mathrm{ppm}$ 로 하절기가 동절기보다 1.7 배 높은 것으로 나타났으며 통계적으로 유의하였다 $(\mathrm{p}=0.004)$. 계절적 요인에 의한 $\mathrm{DMF}$ 의 피부 흡수 역할과 관련하여 선행 연구를 검토 한 결과 이광영 등 15 은 하절기가 동절기보다 2.6 배 높았으나 연구 대상 근로자들에게 모두 개인시료채취 기를 부착하여 개개인 별로 노출된 $\mathrm{DMF}$ 에 대한 소변 중 $\mathrm{NMF}$ 의 배설량을 확인하지 못하여 작업환경중의 $\mathrm{DMF}$ 농도를 적절히 반영하지 못했다고 연구 제한점 을 밝혔다. Mraz와 Nohova는 습도가 $50 \%$ 에서 $100 \%$ 로 상승하고 온도가 $21{ }^{\circ} \mathrm{C}$ 에서 $30{ }^{\circ} \mathrm{C}$ 상승하면 $\mathrm{DMF}$ 의 피부흡수는 3.5 배 증가한다고 하였으나 정인성 등 ${ }^{16}$ 의 연구에서 작업장 내 하절기와 동절기 기온 차이가 10 ${ }^{\circ} \mathrm{C}$ 이고, 습도 차이가 $12 \%$ 이었으며, 피부흡수에 의한 소변 중 $\mathrm{NMF}$ 비율이 전체 배설량의 $50 \%$ 이내인 점 을 고려하면 하절기가 동절기에 비해 2 배 정도 높을 것으로 추정된다.

$\mathrm{DMF}$ 는 호흡기를 통한 흡수뿐만 아니라 점막이나 눈을 포함한 피부경로를 통해서도 쉽게 흡수된다. 따 라서 $\mathrm{DMF}$ 노출에 대한 노출 평가는 외부환경 노출 평가(external dose monitoring)로 공기 중 DMF 농도 외에 내부 노출 평가(internal dose monitoring)로서 생 물학적 노출 평가를 고려하여야 하며 소변 중 NMF가 $\mathrm{DMF}$ 에 노출된 근로자의 1 일 노출지표라고 제시하고 있다. ${ }^{7,23} \mathrm{DMF}$ 노출에 의한 소변 중 $\mathrm{NMF}$ 배설량은 공기 중 $\mathrm{DMF}$ 농도에 의존하는데 소변 중 $\mathrm{NMF}$ 배설 율은 노출 초기부터 증가하여 작업 종료 후 채취한 소변에서 최고조에 이르렀으며 공기 중 $\mathrm{DMF}$ 노출수 준과 24시 소변 중 $\mathrm{NMF}$ 배설량은 선형 회귀관계를 갖는다고 보고되었다. ${ }^{24}$ 공기 중 $\mathrm{DMF}$ 농도와 대사산 물인 소변 중 $\mathrm{NMF}$ 농도와의 상관 관계에 대한 선행 연구들을 검토한 결과 공기 중 $\mathrm{DMF} 10 \mathrm{ppm}$ 에 상응 하는 소변 중 $\mathrm{NMF}$ 농도를 Imbriani 등은 $39.9 \mathrm{mg}$ / $\mathrm{L}$ (37.2 mg/g creatinine), ${ }^{25}$ Wang 등은 $38.4 \mathrm{mg} / \mathrm{L}(39.4$ $\mathrm{mg} / \mathrm{g}$ creatinine)로 제시하였으며, ${ }^{26}$ 국내에서는 1998년 전국 $\mathrm{DMF}$ 취급 사업장 역학조사 결과를 바탕으로 양 정선 등 27 은 피부 및 호흡기 노출그룹의 소변 중 $\mathrm{NMF}$ 를 $39.1 \mathrm{mg} / \mathrm{g}$ creatinine ( $\mathrm{r}=0.424, \mathrm{n}=178$ 명 $)$, 호흡기 노출그룹에서는 $24.2 \mathrm{mg} / \mathrm{g}$ creatinine $(\mathrm{r}=0.743, \mathrm{n}=37$ 명 $)$ 이라 하였고, 최호춘 등은 경기 일부 지역 합성 피혁 사업장(습식 및 건식 방식)을 대상으로 연구한 결과 $\mathrm{DMF} 10 \mathrm{ppm}$ 에 대응하는 소변 중 $\mathrm{NMF}$ 를 $58.6 \mathrm{mg} /$ $\mathrm{L}(\mathrm{r}=0.452, \mathrm{n}=98$ 명 $)$ 로 제시하였다. 본 연구 결과 공기 중 $\mathrm{DMF}$ 농도와 소변 중 $\mathrm{NMF}$ 배설량과의 상관성은
양호한 상관 관계 $(\mathrm{r}=0.650, \mathrm{n}=128$ 명 $)$ 를 가지는 것으로 나타났으며, 회귀관계식에 의거하면 공기 중 $\mathrm{DMF} 10$ $\mathrm{ppm}$ 에 상당하는 소변 중 $\mathrm{NMF}$ 배설량은 $52.7 \mathrm{mg} / \mathrm{L}$ 로 추정되었고, 피부 및 호흡기 노출그룹(방독마스크 미 착용)에서는 $79.9 \mathrm{mg} / \mathrm{L}(\mathrm{r}=0.775, \mathrm{n}=59$ 명 $)$, 피부 노출

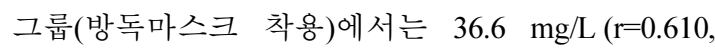
$\mathrm{n}=69$ 명)로 추정되었다.

이번 연구에서는 작업장 내 공기 중 $\mathrm{DMF}$ 농도를 평가하기 위하여 작업자에게 개인시료 채취 펌프를 착용한 능동식 시료 채취 방법 이외에도 펌프 착용을 거부하는 근로자에게는 $3 \mathrm{M}$ 필름 뱃지를 사용한 확산 방식의 수동채취방법을 사용하였다. 시료채취방법에 따른 작업장내 공기 중 $\mathrm{DMF}$ 농도는 확산 방식의 수 동채취방법을 사용한 농도가 $8.83 \mathrm{ppm}(\mathrm{n}=57$ 명 $)$ 으로 개인 시료 펌프를 사용한 능동 채취 방법의 농도 5.77 $\operatorname{ppm}(\mathrm{n}=85$ 명 $)$ 과 유의한 차이를 보이지는 않았으나 비 교적 높은 것으로 나타났다. 하지만 수동채취방법을 사용한 근로자 및 능동 채취 방법을 사용한 근로자의 소변 중 $\mathrm{NMF}$ 농도를 $\mathrm{DMF}$ 농도로 보정한 경우 수동 채취 $6.74 \mathrm{mg} / \mathrm{L} / \mathrm{ppm}$ ( $\mathrm{n}=53$ 명 $)$, 능동 채취 $6.22 \mathrm{mg} / \mathrm{L} /$ $\operatorname{ppm}(\mathrm{n}=75$ 명 $)$ 으로 유의하지 않은 것으로 나타났으며. 선행연구에서 Baglioni 등은 확산방식의 수동 채취방 법과 펌프 방식의 능동 채취 방법 사이의 상관성이 매우 높음을 보고하여 $(\mathrm{r}=0.96, \mathrm{n}=91)^{28}$ 확산 방식의 수 동 채취 방법도 $\mathrm{DMF}$ 취급 근로자의 공기 중 노출평 가로서 유용하다고 평가하였다.

본 연구 결과 $\mathrm{DMF}$ 노출은 피부 및 호흡기 경로를 통해 인체 내로 유입되며, 근로자의 작업 직후 채취한 소변 중 $\mathrm{NMF}$ 는 $\mathrm{DMF}$ 노출에 대한 1 일 노출지표로 유용함을 확인할 수 있었다. 한편, 방독마스크를 착용 하고 작업한 근로자에게서도 요중 $\mathrm{NMF}$ 배설량이 $30.7 \mathrm{mg} / \mathrm{L}$ 로 높게 나온 것은 피부 노출에 의한 것으 로 사료된다. 피부 노출에 대한 중재 효과를 알아보기 위하여 유기화합물용 안전 장갑이나 보호복을 착용한 근로자의 요중 $\mathrm{NMF}$ 배설량을 평가하지 못한 것은 본 연구의 제한점이며, 향후 작업 현장에서 피부노출에 대한 중재 효과에 대한 연구가 보완되어야 할 것이다.

\section{5. 결 론}

본 연구에서는 경인북부지역 $\mathrm{DMF}$ 를 주로 취급하 는 합성피혁제조관련 피혁 및 코팅업체와 잉크 생산 업체 19 개 사업장 및 142 명의 근로자에 대하여 공기 중 $\mathrm{DMF}$ 농도와 생물학적 노출지표인 소변 중 $\mathrm{NMF}$ 
노출수준을 업종, 직무, 보호구착용여부, 계절별로 조 사하였다.

작업장 내 공기 중 $\mathrm{DMF}$ 농도 및 근로자의 소변 중 $\mathrm{NMF}$ 농도는 대수정규분포를 띄었으며 기하평균농도 는 각각 $6.85 \mathrm{ppm}$ 과 $42.3 \mathrm{mg} / \mathrm{L}$ 로 높게 나타났으며, 노출수준 초과율은 공기준 노출기준 $(10 \mathrm{ppm})$ 에 비해 $44 \%$, 생물학적 노출지표인 소변 중 $\mathrm{NMF}$ 기준(15 $\mathrm{mg} / \mathrm{L}$ )에 비해 $87 \%$ 를 초과하였다.

직무별 분석 결과에서, 공기 중 $\mathrm{DMF}$ 농도는 잉크 생산, 코팅, 합지, 배합, 박리 · 포장에서 각각 13.75 $\mathrm{ppm}, 6.74 \mathrm{ppm}, 6.53 \mathrm{ppm}, 6.05 \mathrm{ppm}, 4.70 \mathrm{ppm}$ 이었으 며 소변 중 $\mathrm{NMF}$ 농도는 잉크생산, 배합, 합지, 코팅, 박리 · 포장에서 각각 $54.8 \mathrm{mg} / \mathrm{L}, 45.5 \mathrm{mg} / \mathrm{L}, 44.4 \mathrm{mg} /$ $\mathrm{L}, 38.0 \mathrm{mg} / \mathrm{L}, 33.6 \mathrm{mg} / \mathrm{L}$ 로 소변 중 $\mathrm{NMF}$ 의 노출 기 준인 $15 \mathrm{mg} / \mathrm{L}$ 보다 높게 나타났으나 공기 중 $\mathrm{DMF}$ 농도 및 소변 중 $\mathrm{NMF}$ 농도는 직무별로 유의한 차이 를 보이지 않았다.

보호구 착용에 따른 근로자의 소변 중 $\mathrm{NMF}$ 수준은 공기 중 $\mathrm{DMF}$ 농도를 보정한 경우 방독마스크 미착용 그룹(피부 및 호흡기 노출)이 $9.50 \mathrm{mg} / \mathrm{L} / \mathrm{ppm}$ 으로 착 용그룹(피부 노출) $4.61 \mathrm{mg} / \mathrm{L} / \mathrm{ppm}$ 보다 2 배 높아 유 의한 차이를 보였으며, $\mathrm{DMF}$ 에 대한 피부 및 호흡기 노출 경로는 $48.5 \%: 51.5 \%$ 로 추정하였다.

$\mathrm{DMF}$ 의 피부흡수와 관련한 온도 및 습도 등 계절 별 요인에 의한 근로자의 소변 중 $\mathrm{NMF}$ 수준은 공기 중 $\mathrm{DMF}$ 농도를 보정한 경우 하절기(5월 10월)가 $7.63 \mathrm{mg} / \mathrm{L} / \mathrm{ppm}$ 으로 동절기(11월 4월) $4.53 \mathrm{mg} / \mathrm{L} / \mathrm{ppm}$ 보다 약 1.7 배 높아 유의한 차이를 보였다.

공기 중 $\mathrm{DMF}$ 농도와 소변 중 $\mathrm{NMF}$ 배설량과의 상 관성은 양호한 상관 관계 $(\mathrm{r}=0.650, \mathrm{n}=128$ 명 $)$ 를 가지 는 것으로 나타났으며, 공기 중 $\mathrm{DMF} 10 \mathrm{ppm}$ 에 상당 하는 소변 중 $\mathrm{NMF}$ 배설량은 $52.7 \mathrm{mg} / \mathrm{L}$ 로 추정되었 다. 피부 및 호흡기 노출 그룹(방독 마스크 미착용)의 소변 중 $\mathrm{NMF}$ 는 $79.9 \mathrm{mg} / \mathrm{L}(\mathrm{r}=0.775, \mathrm{n}=59$ 명), 피부 노출 그룹(방독 마스크 착용)에서는 $36.6 \mathrm{mg} / \mathrm{L}$ $(\mathrm{r}=0.610, \mathrm{n}=69$ 명)로 추정하였다. 소변 중 $\mathrm{NMF}$ 농도 는 공기 중 뿐 아니라 피부로 흡수되는 DMF의 노출 수준을 잘 반영하는 지표로서, 이러한 노출 평가 연구 는 국내 $\mathrm{DMF}$ 취급 근로자의 업무 환경 및 건강 개선 에 활용성이 크다고 사료된다.

\section{참고문헌}

1. S. K. Kim, S. J. Lee and K. C. Chung, Korean J. Occup.
Environ. Med., 7(1), 186-190 (1995).

2. Korea Occupational Health and Safety Agency (KOSHA). Study on the management and prevention of rapid poisoning of DMF handling workers, 6-12, 58-61 (2006).

3. American Conference of Governmental Industrial Hygienists (ACGIH), Documentation of the threshold limit values and biological exposure index, Cincinnati, 2013.

4. Ministry of Employment and Labor (MoEL). Permissible exposure limit of hazardous subatance (MoEL Public Notice No. 2013-38) (2013).

5. American Conference of Governmental Industrial Hygienists (ACGIH). Documentation of the threshold limit values and biological exposure index, Cincinnati (1999).

6. Korea Occupational Health and Safety Agency (KOSHA), Workers health examination guideline No. 1 - overview of specific health examination, 209-212 (2012).

7. T. Sakei, H. Kageyama, T. Araki, T. Yosida, T. Kuribayashi et al., Int. Arch. Occup. Environ. Health, 67, 125129 (1995).

8. R. R. Lauwerys, A. Kivits, M. Lhoir, P. Rigolet, D. Houbeau et al., Int. Arch. Occup. Environ. Health, 45, 189-203 (1980).

9. J. Mraz and H. Nohova, Int. Arch. Occup. Environ. Health, 64, 79-83 (1992).

10. T. Nomiyama, H. Nakashima, L. L. Chen, S. Yamauchi, H. Miyauchi et al., Int Arch Occup Environ Health, 74, 224-228 (2001).

11. S. K. Kang, J. Y. Jang, K. Y. Rhee and H. K. Chung, Korean J. Occup. Environ. Med., 3(1), 58-64 (1991).

12. M. D. Joo, Y. D. Sohn and W. I. Choi, J. Korean Soc. Emerg. Med., 17(5), 515-518 (2006).

13. H. K. Chung, S. K. Kang, K. Y. Rhee and J. Y. Jang, Korean J. Occup. Environ. Med., 4(2), 144-150 (1992).

14. K. W. Kim, B. S. Choi, S. K. Kang and Y. H. Moon, J. Occup. Environ. Med., 11(1), 106-112 (1999).

15. K. Y. Lee, J. H. Byeon, H. R. Song, J. H. Kim, K. W. Ko et al. Korean J. Occup. Environ. Med., 15(2), 162172 (2003).

16. I. S. Chung, J. G. Kim, S. K. Choi, J. Y. Bae and M. Y. Lee, Korean J. Prev. Med., 39(2), 171-176 (2006).

17. S. J. Hur, C. H. Suh, C. K. Lee, J. H. Kim, J. T. Lee et al., J. Korean Soc. Occup. Environ. Hyg., 20(4), 225235 (2010).

18. S. W. Lee, T. H. Kim, J. M. Kim and J. C. Kim, J. 
Korean Soc. Occup. Environ. Hyg., 19(2), 113-126 (2009).

19. Korea Occupational Health and Safety Agency (KOSHA). Survey report on the exposure and health impairment of dimethylformamide in korea, 53-92 (1999).

20. H. C. Choi, G. Y. Kim, S. H. Ahn, Y. J. Lee and K. C. Chung, J. Korean Soc. Occup. Environ. Hyg., 11(2), 135-144 (2001).

21. NIOSH Manual of Analytical Methods (NMAM), Fourth Edition, The National Institute for Occupational Safety and Health (NIOSH) (1994).

22. A. Fiorito, F. Larese, S. Molinari and T. Zanin, Am. J. Ind., 32, 244-260 (1997).

23. J. Mraz and H. Nohova, Int. Arch. Occup. Environ. Health, 64, 85-92 (1992).
24. J. Yonemoto and S. Sunuki, Int. Arch. Occup. Environ Health, 46, 159-165 (1980).

25. M. Imbriani, P. Marraccini, G. Saretto, L. Abatangelo, S. Ghittori et al., Med. Lav., 91(2), 114-124 (2000).

26. V. S. Wang, T. S. Shih, C. C. Cheng, H. Y. Chang, J. S. Lai et al., J. Occup. Environ. Med., 46(7), 729-736 (2004).

27. J. S. Yang, E. A. Kim, M. Y. Lee, I. J. Park and S. K. Kang, Int. Arch. Occup. Environ. Health, 73(7), 463470 (2000).

28. S. Baglioni, C. Cassinelli, G. Bongini, I. Cenni, N. Graziani, M. Landini, G. Tanturli, M. Brabec and P. Bavazzano, Int. Arch. Occup. Environ. Health, 80(3), 228-33 (2007). 